\title{
Hotel lending by European commercial banks: Survey results
}

Received (in revised form): 22 September 2005

\begin{abstract}
Allen Toman
teaches corporate finance and real estate finance at ECOLE HOTELIERE LAUSANNE, holds advanced degrees in public finance and philosophy, and is a doctoral candidate at Cornell University. His research interests include hotel and hotel company valuation; real estate loan default; and, hotel management agreements. Prior to his current position he held, industry positions with development; ownership and advisory firms. He is a member of the International Society of Hotel Consultants.
\end{abstract}

\begin{abstract}
The formation and expansion of the European Union over the past decade has had numerous impacts on the economies of its members and the global capital markets. For the banking and real estate sectors, the impacts have been slower to take effect as these industries remain subject to controls and traditions of the individual countries. Hotel companies and investors have aggressively moved 'cross-border' to develop, acquire and invest in hotel real estate. However, the availability of debt to finance these transactions and the transparency of this industry remain as issues. This study involved a survey of 'western' European banks both to identify those involved in hotel lending and to better understand key underwriting terms. The survey focuses on four basic issues: level of involvement in hotel lending; scope of lending in terms of geography and types; key underwriting terms; and, perceived impacts of the Basel II accords. The results are reported for major lenders (exposures greater than 500 million) and smaller lenders. The results indicate that the smaller lenders tend to be more conservative in terms of geography and product, but somewhat more aggressive in underwriting terms. It is also found that banks tend to focus only on their national markets and that the majority of lending involves traditional loan products held in the originators portfolio.
\end{abstract}

\section{Keywords:}

hotel debt, European union banks, European hotel lenders, loan-to-value, debt service coverage

Journal of Retail and Leisure Property (2006) 5, 134-147. doi:10.1057/palgrave.rlp.5100012

\section{INTRODUCTION}

The traditional 'bedrock' of hotel real estate debt financing in Europe has been commercial banks, especially for single asset transactions involving 
construction, acquisition or repositioning. Potential lenders include domestic banks (local, regional or national) as well as international banks. ${ }^{1}$ However, not all lenders choose to participate in lending to hotels as real estate, and hotel real estate in particular, as hotels are considered specialised assets.

Hotels are traditionally recognised to involve inherently more risk than other forms of asset backed real estate. ${ }^{2}$ This risk is due, in large part, to four factors inherent to lodging properties that contribute to the volatility of the revenue and/or income levels achieved. The factors include: ${ }^{3}$

- Rate volatility: in effect, hotel rates are marked-to-market on a daily basis. As such, hotel revenues respond quickly to changes in both macroeconomic and local economic factors.

- High operating leverage: hotel's, especially in the full-service category, have high-fixed costs that are, in the short term, independent of revenue levels.

- Cyclicality: the sensitivity of achieved lodging revenues (and income) to changes in economic variables both in terms of the creation of new supply and the level of future demand.

- Management intensiveness: the dependence on management performance over time to achieve revenue and income levels.

As the real estate and hotel loan syndication market remains relatively undeveloped in Europe, ${ }^{4}$ European banks tend to retain loans in their own portfolio. Thus, they to bear the full risks of the hotel loans they originate. Given the experience of the prolonged economic downturn of the late 1980s and early 1990s, many lenders became wary of real estate lending and, in particular, lending backed by hotel real estate. The industry abounds with stories of developers and owners of existing hotels searching among a variety of domestic and international banks for hotel debt financing.

The current increase in cross-border transactions within Europe, increasing market transparency and the increase in sales volumes ${ }^{5}$ makes identifying and understanding the requirements, preferences and intentions of banks that lend to hotels of even greater interest. As there is, at present, no regular, public exchange of hotel lending information (outside of periodic hotel investment conferences), a study team comprised of Ecole hôtelière de Lausanne faculty, research assistants and students undertook a six-month effort to identify and survey hotel lenders.

\section{SURVEY HIGHLIGHTS}

The hotel asset lending market appears to be divided among a handful of lenders with large (100 million to several billion euros) portfolios (and specialised hotel lending groups) and other banks with relatively small (under 100 million euros) exposures. The 'typical' hotel mortgage can be characterised as:

- Secured by a mid-price hotel located in a city that is in the same country as the lender. 
- The mortgage is amortising with a term of approximately 15 years based on an amortisation period of 15-25 years.

- The interest rate is variable (some $60 \%$ of all loans)

- The loan to value ratio is: - More than $65 \%$ for the lenders with large exposures - Less than $65 \%$ for the lenders with small exposures

- The debt coverage ratio is between 1.21 and 1.35

Both groups reported a moderate preference for hotel loans involving renovation/repositioning in contrast to refinancing or acquisitions.

While a large majority of the lending transactions were made within the lender's home market, there was an indication that the larger lenders are somewhat geographically diversified as approximately $1 / 3$ of their loan portfolio is committed to other EU markets or to markets outside of the EU. The majority of loans were retained in the portfolio of the originator; however, the larger lenders indicated that some $25 \%$ of their portfolios were subject to alternative, or shared, ownership through syndicated transactions or participations.

\section{THE SURVEY 6}

The survey team consisted of some 20 members from the Ecole hôtelière de Lausanne community working over a period of six months. Nearly 250 potential lenders were identified and some 60 of these were qualified as being hotel lenders. Of these 60, 26 (43\%) participated in the survey representing 10 countries in Western Europe. ${ }^{7}$ The participants included eight of the largest banks (ranked by total assets) in Europe. The breakdown of the lenders by portfolio size included:

- Fifteen lenders with hotel loan portfolios in excess of 100 million euros. Five of these reported hotel loan portfolios in excess of 500 million euros, with several in excess of 1 billion euros. ${ }^{8}$

- Eleven lenders with hotel loan portfolios less than 100 million.

The survey process was divided into four stages:

- Primary and secondary research to identify lenders with hotel asset exposures.

- Development and testing of survey instrument and a secure, electronic survey administration tool.

- Administration of the survey through both electronic mail and personal contacts. The survey instrument was provided in English as well as in nine different languages. Where necessary, follow-up calls were made to clarify or verify responses.

- Collection and analysis of the results.

On the advice of several lenders, financial consultants and colleagues, the survey instrument was kept short and direct. ${ }^{9}$ This was done in part to encourage increased participation by lenders and in part in realisation that lenders would be unlikely to share (or in some cases would not be able to 


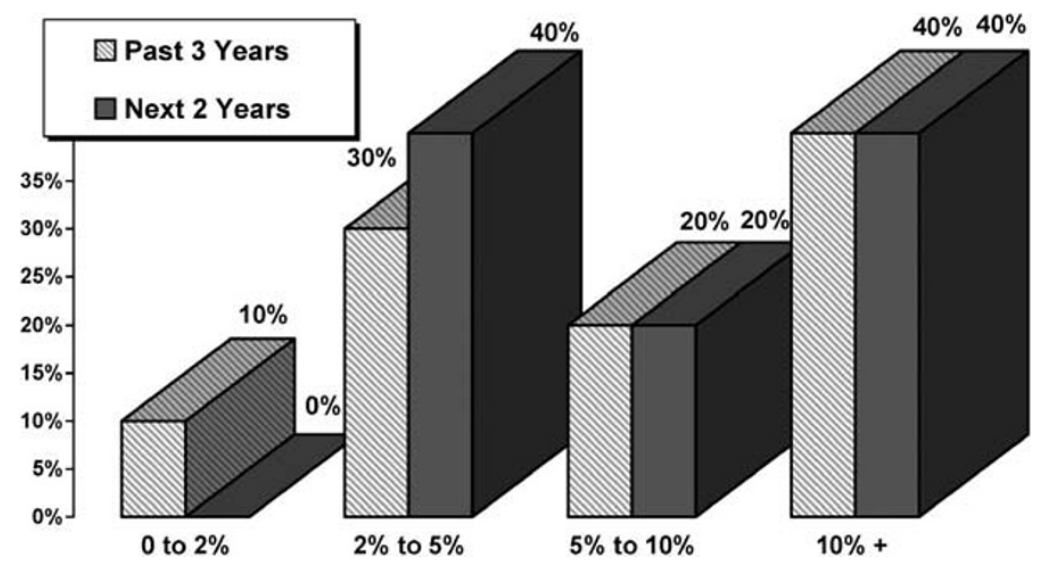

Figure I: Large lenders real estate as \% of overall lending portfolio

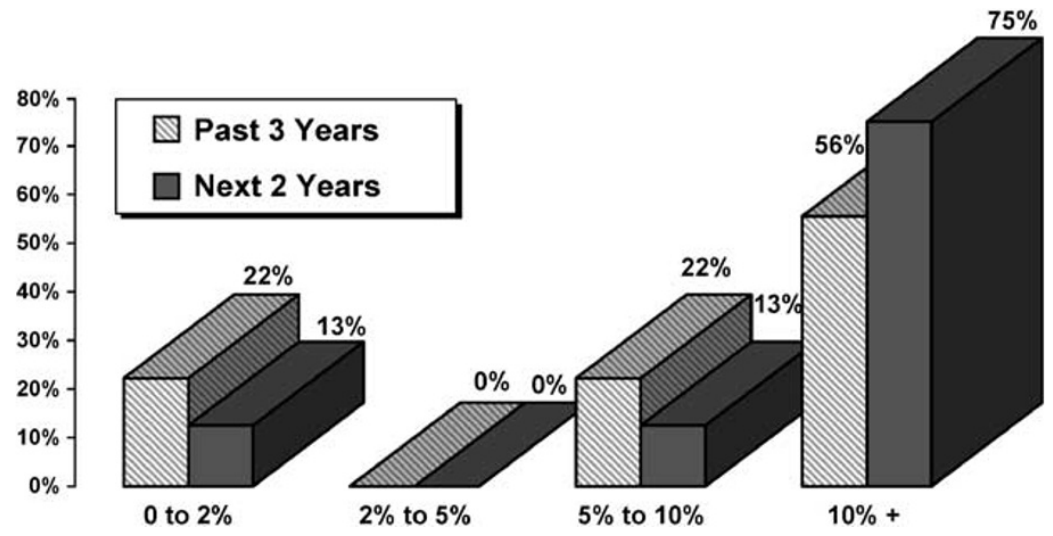

Figure 2: Small lenders real estate as \% of overall lending portfolio

access) detailed information that would require additional analysis or that was considered proprietary. ${ }^{10}$

\section{Lender portfolio data}

The participants were asked to provide details regarding the relation between their historic (past three years) and their expected (next two year) real estate portfolio and their overall lending portfolio. Figure 1 shows the results for the 'large lenders' $(100+$ million hotel lending portfolio) while Figure 2 reports results for the 'small lenders' (under 100 million euro hotel loan portfolios). Lenders (40\%) with larger hotel portfolios report that real estate lending represents more than $10 \%$ of the bank's overall lending portfolio. Over $50 \%$ of the smaller lenders report a real estate loan concentration greater than $10 \%$ of their overall portfolio, and this number is expected to grow to $75 \%$ over the next three years.

Hotel lending as a percentage of real estate lending (Figure 3) was relatively equally divided with some $50 \%$ reporting levels below 5 and $50 \%$ reporting levels above 5\%. Both groups tend to retain full ownership of the loans they originate (Figure 4); however, over $20 \%$ of the large 

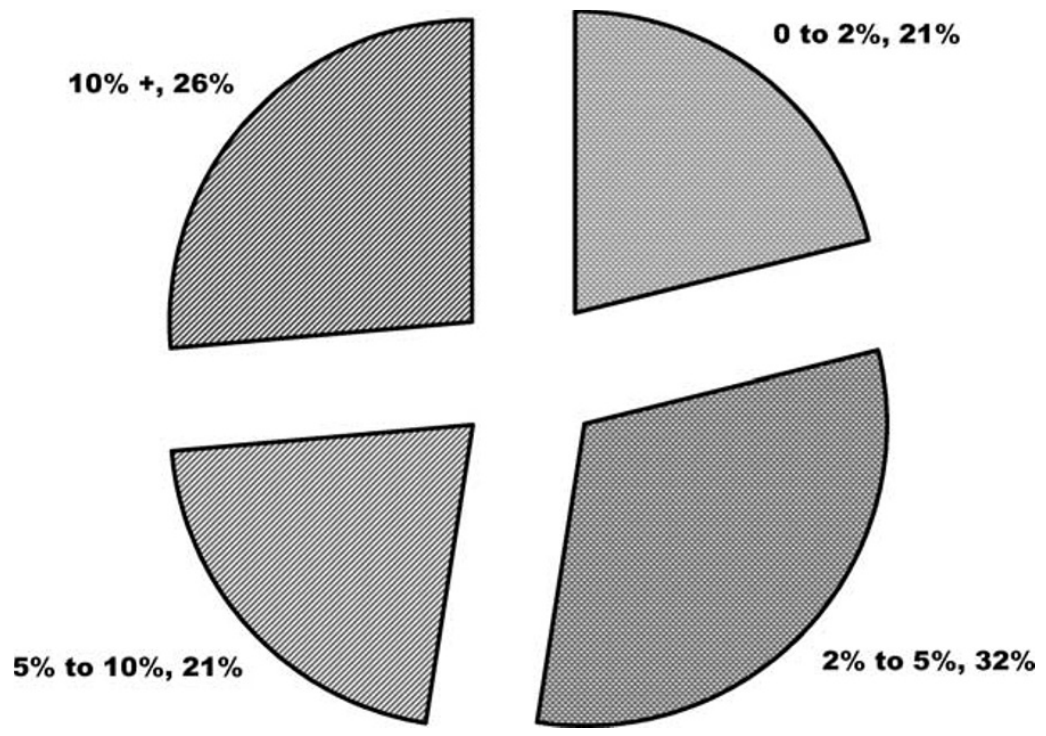

Figure 3: Hotel lending as \% of real estate lending

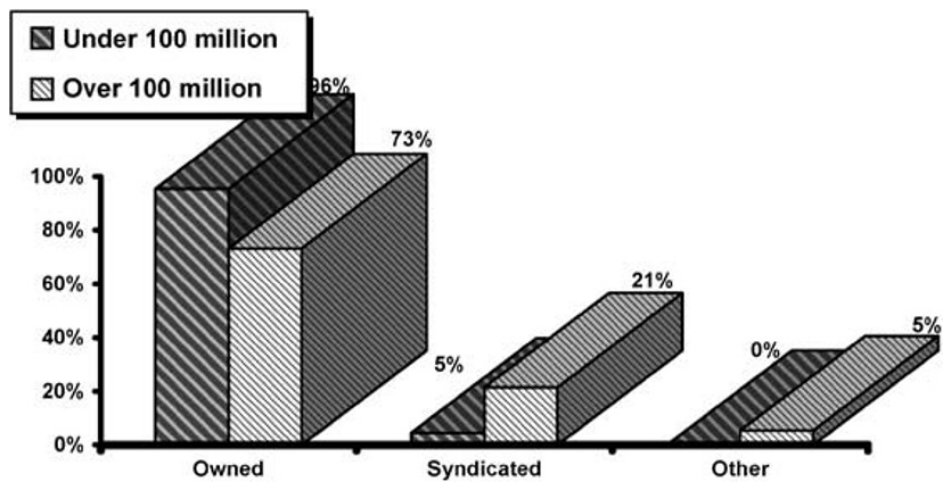

Figure 4: Ownership of mortgages

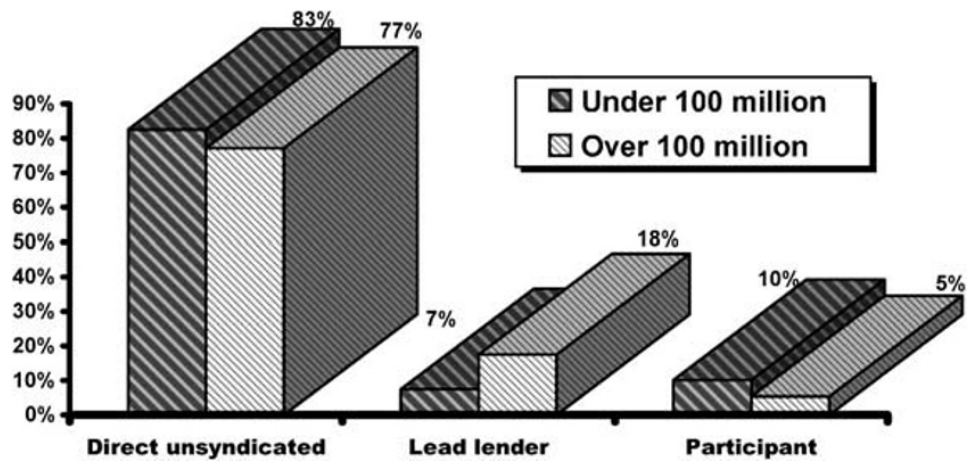

Figure 5: Source of origination

lender portfolios consist of syndicated loans. Both groups report that some $80 \%$ of their lending activity is sourced directly rather than through third parties or other lenders. 


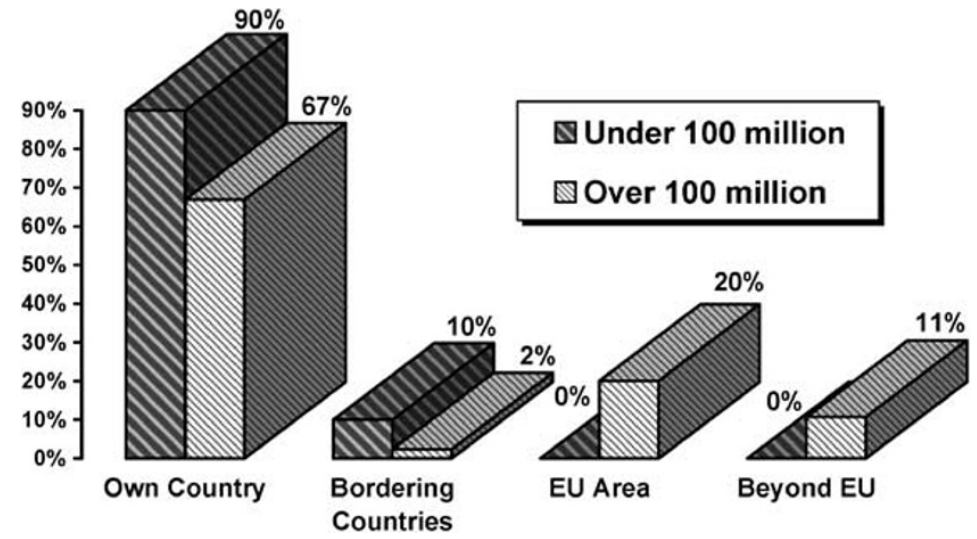

Figure 6: Location of mortgage collateral

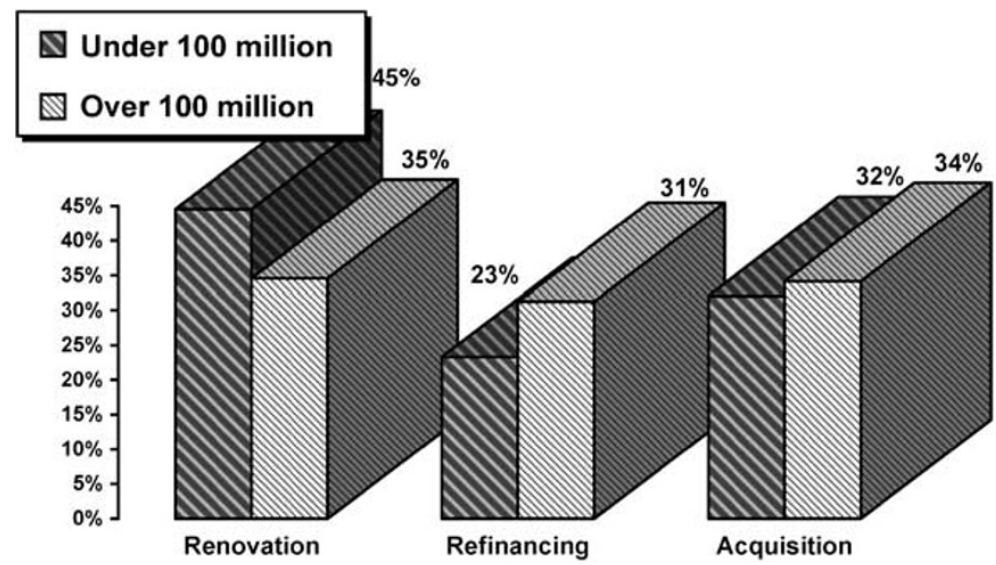

Figure 7: Use of loan proceeds

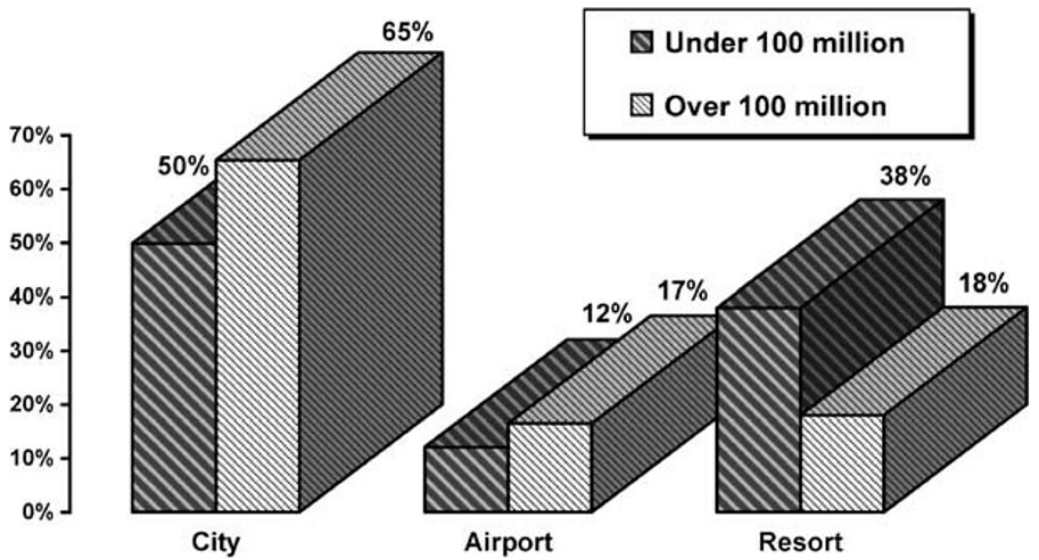

Figure 8: Location of collateral

\section{Sources and ownership of mortgages}

The portfolio of the smaller lenders appears to consist mostly of whole mortgages (Figure 4) while the larger lenders more frequently participate in syndications and other indirect lending. Both groups tend to source 

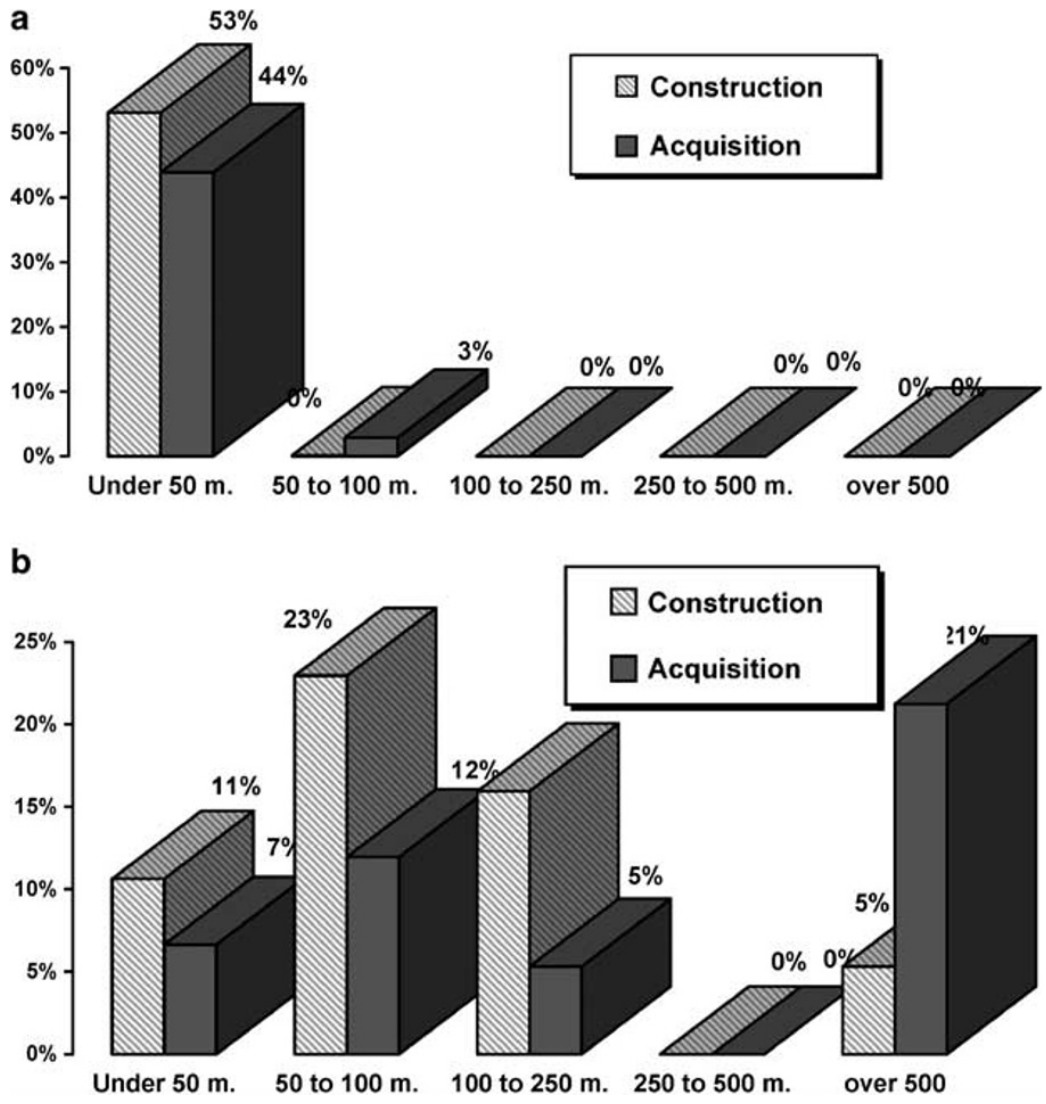

Figure 9: (a): Smaller lender portfolio allocation. (b): lender lender portfolio allocation

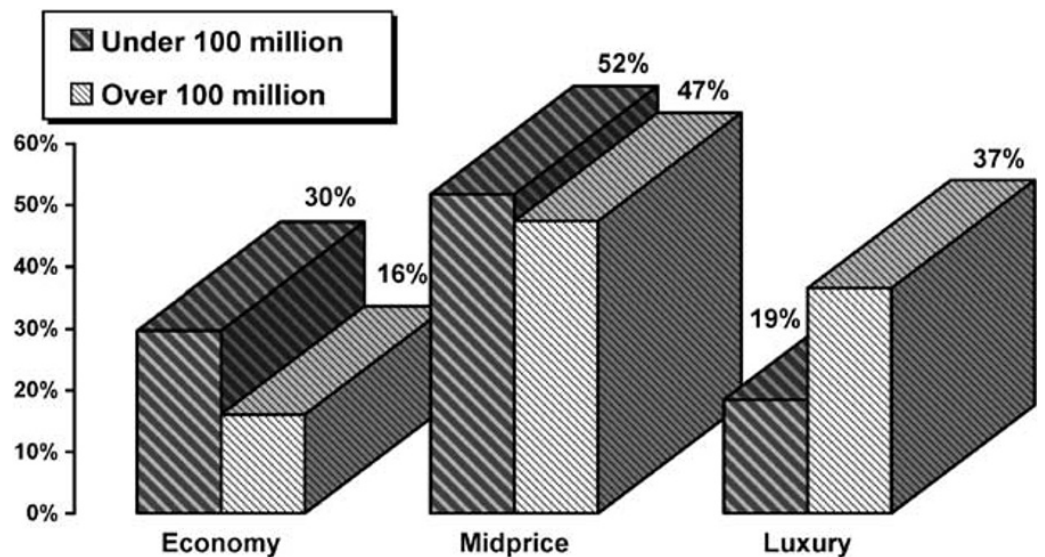

Figure 10: Portfolio by hotel type

opportunities directly (Figure 5), and where the larger hotel lenders are involved in syndicates, it appears they are generally the lead lender.

\section{DISTRIBUTION AND USE OF PROCEEDS}

The geographic distribution of loans (Figure 6) was heavily weighted towards the domestic market of the lender $(90 \%$ for the small lenders and 


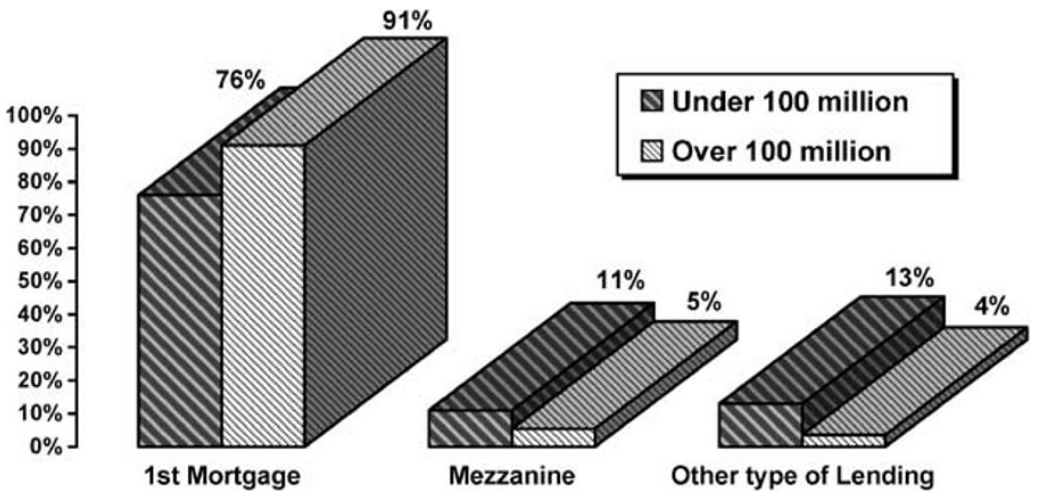

Figure II: Portfolio by mortgage type

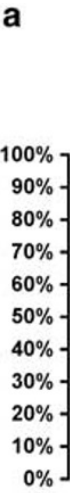

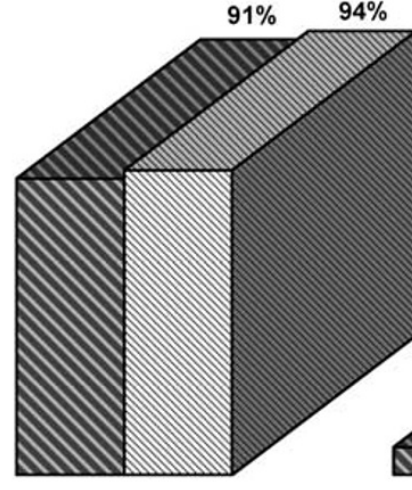

Amortizing

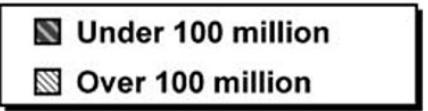

Interest Only

b

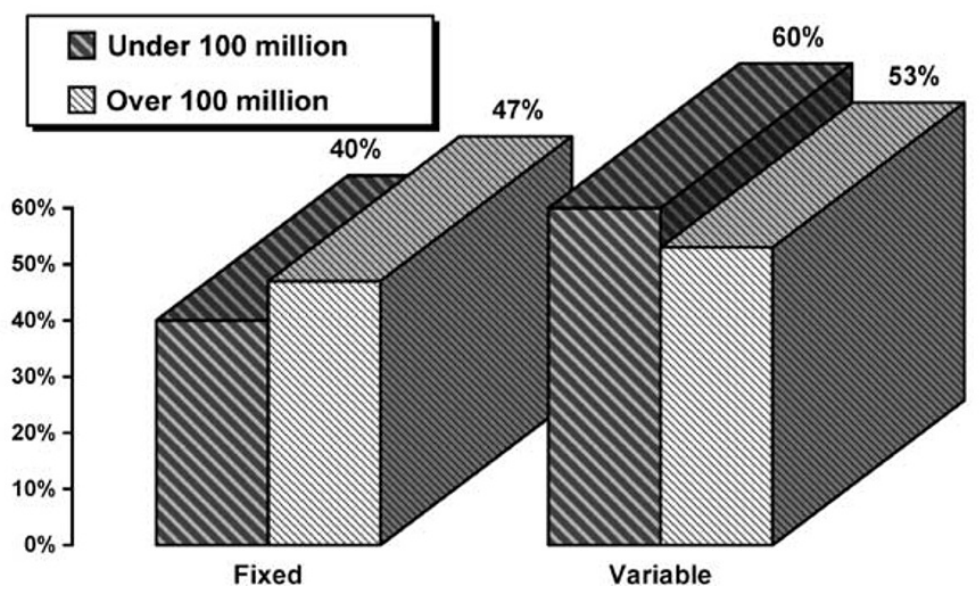

Figure 12: (a): Portfolio by amortising versus interest only. (b): portfolio by fixed versus variable interest

$67 \%$ for the large lenders). Only the 'large' hotel lenders have loans outside of their domestic, or immediately bordering, markets. Several of the respondents indicated that loans outside their domestic market were either portfolio driven or extended to domestic clients entering into crossboarder investments. One would anticipate a significant shift in these percentages over the coming years given recent increases in cross-border hotel acquisitions, increases in international brand presence and increases in hotel portfolio transactions. ${ }^{11}$ 


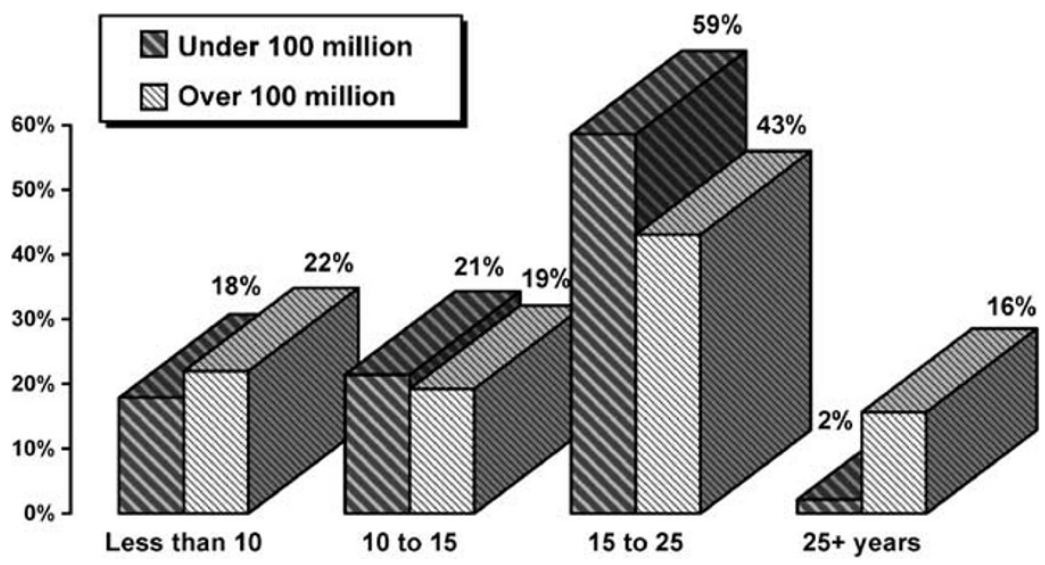

Figure 13: Portfolio by amortisation term

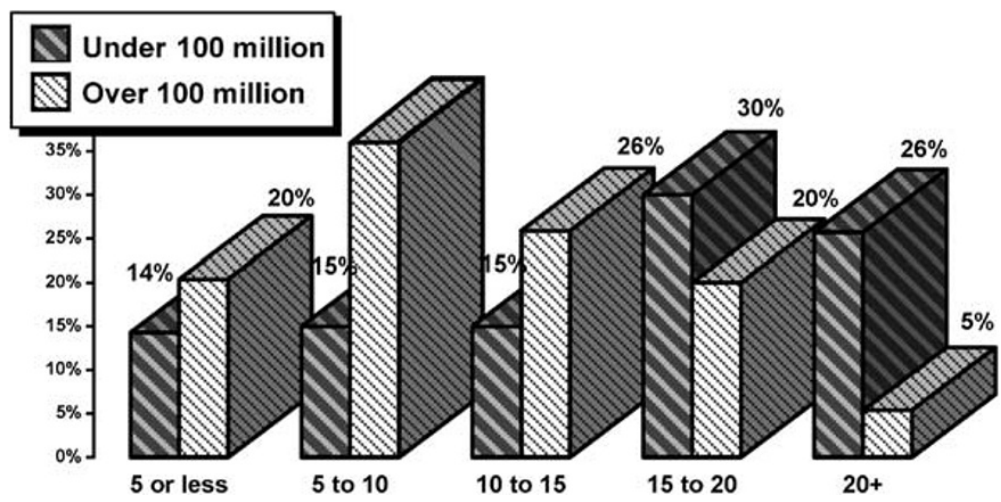

Figure 14: Portfolio by mortgage term

The lenders with smaller hotel portfolios expressed a preference for renovation/repositioning transactions (Figure 7). The lenders with larger hotel portfolios were equally divided between loans for renovation, refinancing and acquisition. Both groups (Figure 8) reported a preference for city locations; however, the smaller lenders report some $50 \%$ of their hotel portfolios as resort and airport locations. Both groups have some $50 \%$ of their portfolios in loans to the mid-priced hotel segment. The small lenders report economy hotels as the second most represented group in their portfolios (30\%) while the large lenders have a similar weighting in resort hotels.

Somewhat surprisingly, as illustrated in Figure 9A and B, both the smaller and the larger lenders tend to have a heavier weighting in construction versus acquisition financing (over 50\%). Figure 9B also shows that larger lenders have some $25 \%$ of the portfolios in extremely large exposures (500 million or more) which likely represents portfolio transactions.

Both category of lender reported that some $50 \%$ of their total hotel lending involved midprice hotels (Figure 10). Somewhat surprising was the level of lending by the smaller hotel lenders in the luxury category $(19 \%)$. 


\section{UNDERWRITING AND LOAN TERMS}

Both groups reported a high percentage of their hotel loan portfolios are in the form of first mortgages (Figure 11). The 'small lenders' reported nearly $25 \%$ of their portfolios were held in the form of mezzanine $(11 \%)$ debt or other forms of hotel lending (second mortgages, working capital loans, etc.).

Nearly $90 \%$ of the loans for both groups are amortising (Figure 12A) and the majority for both groups have a variable rate of interest (Figure 12B). However, the two groups diverge in terms of amortisation period (Figure 13) and loan term (Figure 14). The small lenders report both longer terms (over $50 \%$ of their loans are for terms longer than 15 years) and longer amortisation periods (nearly $60 \%$ greater than 15 years). In contrast, the large lenders report the majority of their loans are for shorter terms (over $50 \%$ less than 10 years) with similarly long amortisation periods (60\% greater than 15 years).

Part of the divergence in loan terms and amortising periods is reflected in the difference between the two groups of lenders in respect to loan-tovalue (Figure 15) and debt-coverage ratios (Figure 16). The small lenders mitigate some of the longer term and amortisation period risk by, in general, issuing loans with more conservative coverage ratios. For example, the distribution of the small lender loan-to-value ratios are skewed toward the low end with over $70 \%$ of the loans ratios below $65 \%$ (18\% at $50 \%$ or less) and a higher proportion of their loans (37\%) have debt coverage ratios above 1.35 while $33 \%$ are below 1.20 . The large lenders tend to have more loans with higher loan-to-value ratios $(70 \%$ of their loans at $65 \%$, or more) and lower-debt coverage (29\% above 1.35 and only $7 \%$ below 1.20 ).

\section{Basel II accords}

One of the 'threats' that may be of particular concern to hotel lenders and borrowers in the coming years are the Basel II Banking Accords. These revised accords are scheduled to take effect in 2006. While the interpretation and implementation of many of the procedures remain in question, the overall goal of the accords is to move beyond the existing accords to more clearly align lender risk positions with the level of reserves maintained by those lenders. ${ }^{12}$ In effect, loans to asset classes involving higher risk will result in higher capital reserve requirements. Such loans will, in turn, have a negative impact on lender returns unless the additional risk is fully priced. Ultimately, these changes should translate into pricing as well as supply and demand impacts for riskier credits.

The risk weighting methodology incorporated into the Basel II accords allows lenders to pick a 'standardised', proscribed, weighting scheme or to either partially or fully develop their own ratings based on models of default and loss. Hotel real estate is generally considered a high-risk asset. ${ }^{13}$ If this is correct, the Accords may result in higher risk ratings for hotel loans which, in turn, could result in hotel lenders having to increase their reserves. Increased reserves should lead lenders to require higher returns (i.e. increased rates or fees) in order to maintain their required 
return on equity levels. And, higher rates should impact demand and supply (as well as the pricing) of hotel real estate loans. ${ }^{14}$

Respondents were asked to assess the likely effect of the Basel II Accords on their hotel lending volumes and on hotel lending rates. Some two-thirds of respondents (see Figure 17A and B) indicated that they did not foresee any effect on either lending volumes or rates at their institution. However, 30\% (7) of those responding to this question indicated that interest rates charged for hotel lending would rise with the implementation of Basel II.

\section{CONCLUSION}

One of the interesting results of the survey is the risk position of the larger lenders. These lenders report larger loans made at higher loan-tovalue ratios with longer amortisation periods and more weighting in construction lending. While these factors may contribute to increased risk, they are somewhat mitigated by the shift to variable rate loans and shorter terms. The smaller lenders reported more conservative

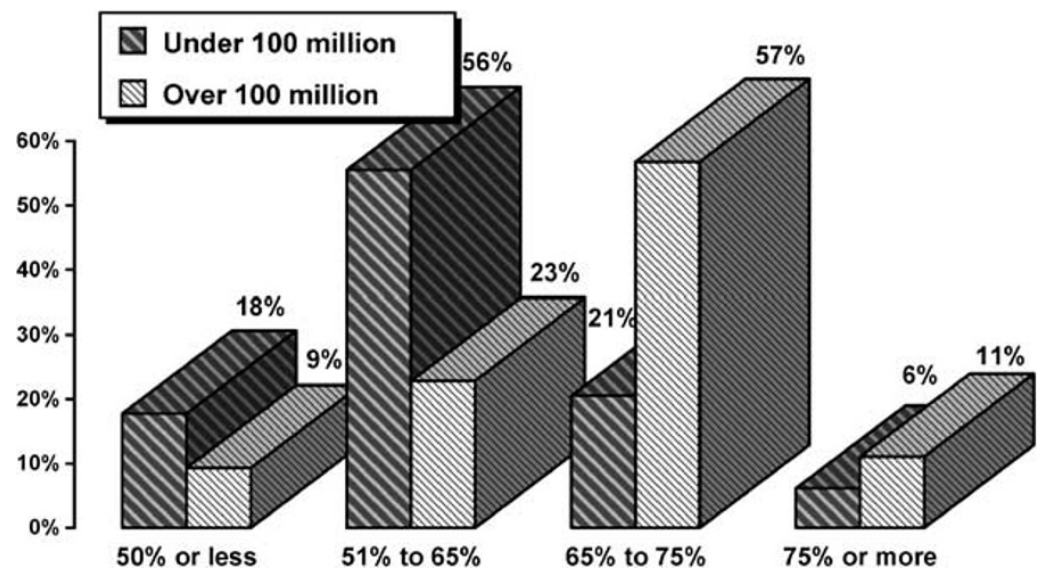

Figure I5: Portfolio by loan to value ratios

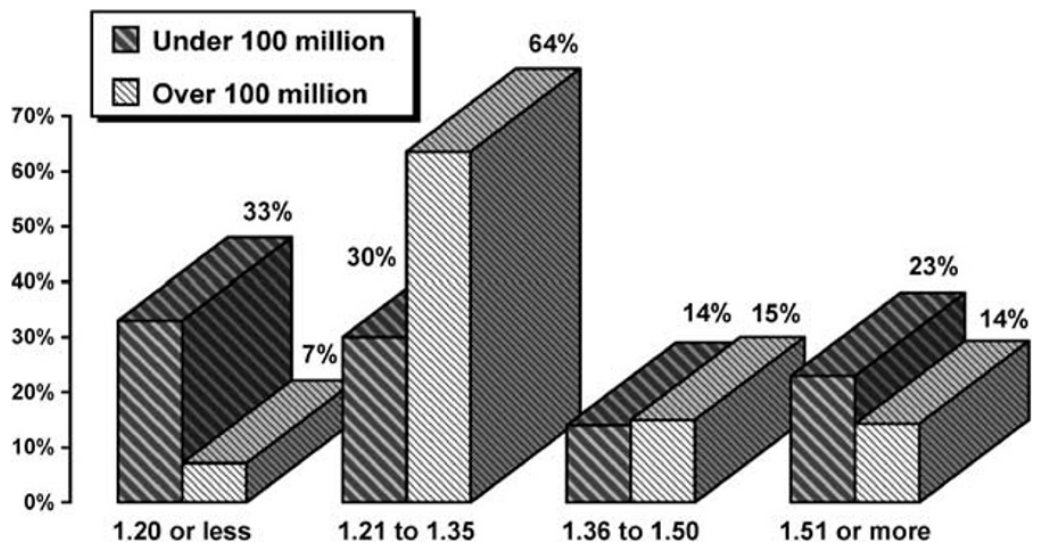

Figure 16: Portfolio by debt coverage ratios 

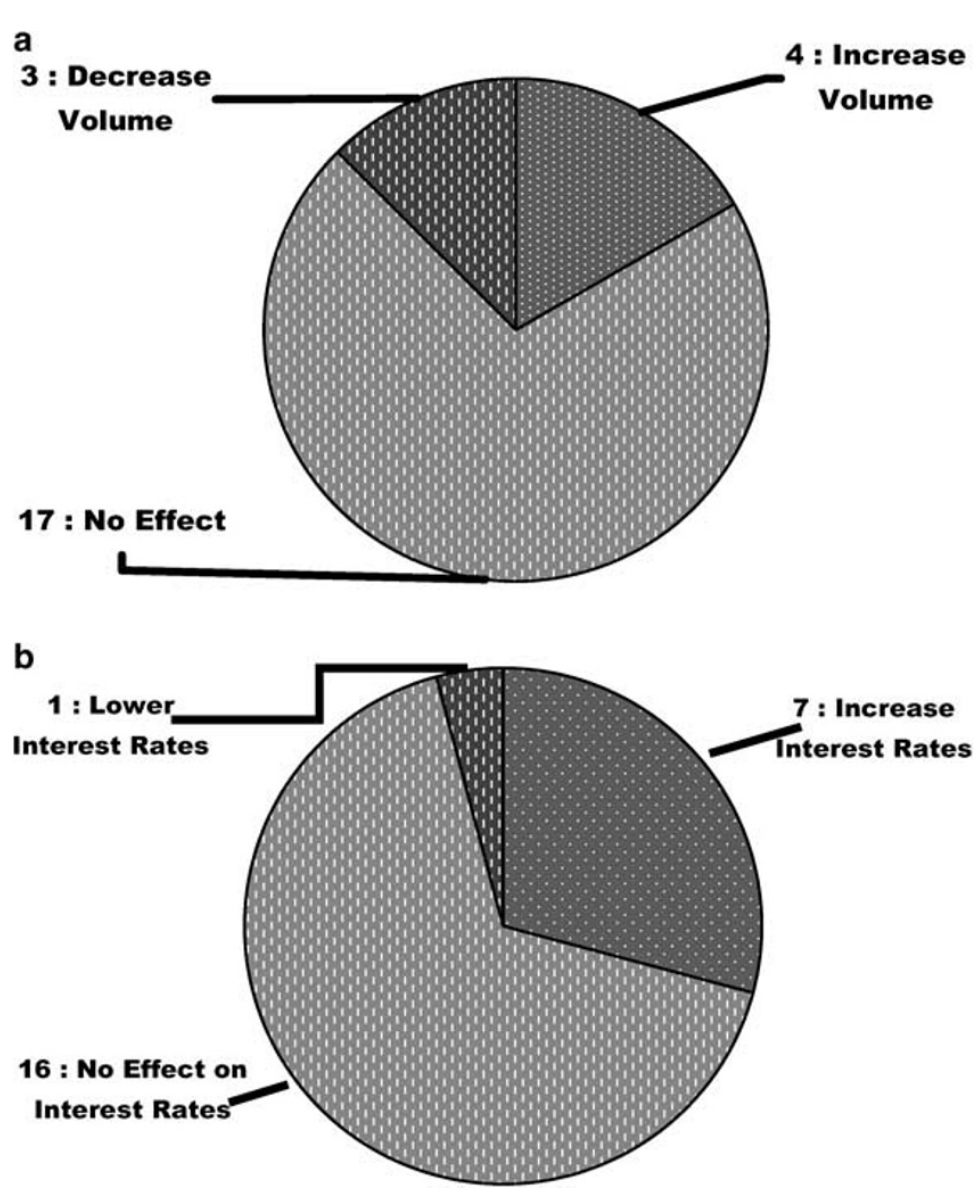

Figure 17: (a): Basel accords \& loan volume. (b) Basel accord interest rate

underwriting results, except their loans tended to have longer terms and a higher presence in resort product. Both groups have limited diversification in terms of country-risk.

While the survey provides information on the practices of one source of hotel lending in Europe, it is far from a complete picture as the financial landscape in Europe is rapidly evolving:

- European banks have traditionally been domestic banks focused on relationship lending. The lack of geographic distribution (crossborder) reported in the survey is consistent with this tendency. While many banks have opened operations in multiple European countries, their activities have generally been confined to financing business operations and investment banking activities. Recent cross-border bank acquisition activity (i.e. buying the ability to offer a full line of banking services) should bring new competition and greater geographic distribution to the banking industry.

- While European insurance companies and pension funds play a smaller role in hotel financing than in United States, the recent Accor sale-leaseback of 128 hotels to a consortium of French institutions may also be a sign that institutions will take a greater role in real estate/hotel financing. 
- A series of portfolio and company transactions involving opportunity funds, many involving substantial hotel assets, have provided an increased presence of debt sourced (or provided) by investment banks. Many of these transactions (for example: Meridien and Intercontinental) have also involved assets located in a number of markets.

- While still small, compared to the US, the rapid increase in CMBS could eventually provide a significant source of debt financing for the industry and a more active participation by insurance companies and pension funds.

- The growth of REIT type vehicles within various EU countries will provide not only greater transparency in the asset and lending markets, but could also lead to developing (in parallel with the US) mortgage REITs.

Over the past decade, the increased presence (and number) of firms with specialists focusing on the hotel industry in Europe has led to an increase in the amount of information available and the quality of that information. However, there is still much to be done before the level of information on hotel operating results and hotel finance approaches the resources available to investors in the US and, even then, surveys of various industry participants may still be useful in order to draw together disparate information.

\section{References and notes}

1. Switzerland and the EU are headquarters to 17 of the top 25 banks in the world as measured by total assets. See: The Banker (2004), 'Top 1000 World Banks, July 2, 2004.

2. For a succinct discussion of risks inherent to hotels see Stephen, R. and George, G. (1997), 'Hotel value trends: yesterday, today, and tomorrow', Cornell Hotel and Restaurant Administration Quarterly, December 1997; Vol. 38, No. 6.

3. In a 2003 interview with Jones Lang LaSalle, Johnathan D. Gray, Senior Managing Director, Blackstone Real Estate Advisors notes that the additional risk of investing in hotels because hotel investments offer two important upside plays: '(1) hotels are often operationally inefficient so a new owner can bring management expertise to bear; (2) cycles play a significant role and allows opportunistic investors the ability to take advantage of "distress points".' See Jones Lang LaSalle Hotels (2003), 'A global comparison of hotel and office real estate: investor insights-part 1', July 2003.

4. Morgan Stanley Research in a 2004 study of CMBS issuance in Europe illustrates that the European CMBS market lags the development of the US by approximately one decade. However, over the past two years the pace of CMBS issuance in the European markets has accelerated at an increasing pace, Morgan Stanley Research (2004), 'European CMBS'.

5. See for example: Bock, P and Forster, B (2004), 'European hotel transactions 2004', HVS International: London', The authors note that non-domestic transactions rose to 4 billion euros out of an estimated 8.9 billion euros in overall transaction activity. They further note that some $40 \%$ of this cross-border transaction volume involved single assets. Or Rene-P S. (2005) 'The European hotel investment market — current players and trends', Ecole hôtelière de Lausanne Institute of Technology \& Entrepreneurship Magazine, Issue \#8, March 2005. Mr Schappner notes that within Europe: 'Over the past years, increasing market transparency — supported by the single currency in most EU countries — but also the need for diversification have convinced investors to start investing in other countries.'

6. Financial support and general encouragement for the survey was provided by Horwath Hospitality and Leisure. They graciously agreed that all contact information and survey data would remain confidential to be viewed, and analysed, only by the faculty and academic assistants from the Ecole hôtelière de Lausanne survey team.

7. Initially the survey was to include the EU-25 plus Switzerland. However, this goal was abandoned given the lack of lenders who would cooperate or who could provide reliable information. 
8. A prior survey from April 2004: 'Hotel Debt Financing' issued by Jones Lang LaSalle Hotels (and conducted by Ecole hôtelière de Lausanne students) involves a smaller sample, focuses more on lender criteria and does not differentiate between lender portfolio size.

9. Nearly half the lenders would not, or could not, provide more detailed information by hotel segment level. Partial results obtained for a number of segment related survey questions are not incorporated in this discussion. Several of the domestic banks reported that hotel lending decisions were 'decentralized' and that specific information on those transactions was not available at the corporate level.

10. See for example: Giannouka, Katerina and Smith, Karen, '2005 European Hotel Valuation Index', HVS International, March 15, 2005 or Geographic distribution may also be impacted by crossborder bank acquisitions such as the recent acquisition/merger of HVB, a German bank and UniCredit of Italy.

11. For a summary of the anticipated accords see: Bank for International Settlements (2004), 'Basel II: International Convergence of Capital Measurement and Capital Standards: a Revised Framework.

12. In Basel II, real estate is considered one of the higher risk categories. Banks with significant real estate experience and exposure may opt to use in-house models that reflect their specific portfolio attributes; however, such models may require significant investments.

13. For an example of the wide range of uncertainty regarding the rules, the implementation process and the effects of the accords, see the remarks by Governor Mark W. Olson of The Federal Reserve Board of Governors delivered in Washington, DC in May of 2005. See Governor Olson Mark, W. (2005), 'Remarks by Governor Mark W. Olson'. Annual Washington Briefing Conference of the Financial Women's Association, Washington, DC, May 16, 2005.

14. Bank of International Settlements, Basel Committee on Banking Supervision (2005), 'Working paper No. 14: studies on the validation of internal rating systems', Revised version: May 2005.

15. Deloitte \& Touche LLP (2004), 'The Hotel Benchmark Survey'. 